\section{David Arendale \\ Terms of \\ Endearment: Words that Define and Guide Developmental Education}

White the issue of redefining the developmental education profession has been a constant in its history, the urgency to reexamine it has never been greater. As practice advances and changes, so must the language to describe it. This reexamination can be an opportunity to transform the work of the field, expand its borders, and redefine its essential role within postsecondary education. The developmental education profession has been identified by a variety of terms: academic preparatory program, remedial education, compensatory education, learning assistance, developmental education, and access program. This article argues that the field must articulate new language to help others better understand and support its efforts. New language may help professionals in the field recognize common goals and lead to more support for students and more effective positioning of programs to better meet institutional priorities

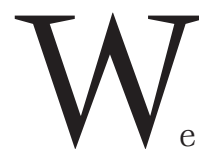
in words and data fueled by the explosive growth of information sources through the Internet as well as the traditional print media of newspapers, newsletters, journals, and magazines. It appears that we are drowning in data and yet starving for meaningful knowledge. Several consequences have resulted from this growing pool of data.

The first is that different words begin to be used interchangeably, regardless of whether they mean the same thing. Sometimes words become so generically used that the original purpose becomes lost. How often have you heard someone ask for a Coke, when actually a Pepsi or another soft drink was desired? While this example is relatively harmless (except to the legal department at Coca Cola ${ }^{\circ}$ ), precise language is needed to accurately differentiate objects and ideas. A current example within higher education is the too often interchangeable use of the following phrases: cooperative learning, collaborative learning, and learning communities. While each term shares common characteristics with the others, the precise meanings are quite different.

Rice (1980) argued that language often reflects the culture and confusion that exist within the culture. He exhorted educators to be precise in the use of language, especially in regard to technical vocabulary used to describe the education profession. In my previous writings, I have used some of the terms described in this article interchangeably. With my new position teaching history, I have devoted more time to the study of the history of the field that has been formally called developmental education. As I have studied this history, I have grown to appreciate the nuances and differences between the words and their historical meanings.

A second consequence for inappropriate vocabulary choice is that some words take on new and different meanings based on the agenda of a few individuals (Clowes, 1980; Rubin, 1987). Sometimes vocabulary becomes politicized by assuming a different meaning or value because a small group within society has affixed a positive or negative status with the word. This is most powerfully displayed by some policy makers at the local or state level who promote a negative stereotype of remedial education and compensatory education (Astin, 1998; Clowes, 1980; Higbee, 1993; Payne $\mathcal{E}$ Lyman, 1996). While these educational practices may have been embraced fifty years ago, during the present political climate there are some who advocate the elimination at the postsecondary level anything that is associated with those terms. Seven states have or are in the process of eliminating developmental education courses, such as Basic English or Study Skills, at the public four-year college level (Abraham \& Creech, 2000, p. 11). Some even advocate for its elimination within public two-year colleges as well (McGrath \& Spear 1994). This controversy over the profession is certainly not new. Bridging the academic preparation gap has been a constant in the history of American higher education and that the controversy surrounding it is an American educational tradition (Brier, 1984, p. 2).

Individual words are important and need to be used properly. This article reviews the most commonly used phrases to describe the field and practice of developmental education. I advocate that rather than promoting the most politically acceptable term, the word choice should be governed by what is the most appropriate phrase that accurately 
describes the services, target student population, and purpose of the field. If we as educators cannot effectively articulate and communicate these words, we risk being defined by others.

The order used to list the terms is by chronological occurrence within the professional literature. I recognize that my use of "developmental education" may not be embraced by all professionals withinthis field and practice. For practicality of authoring, I selected it as the most recent of the accepted terms.

\section{Academic Preparatory Programs}

Beginning in the early 1800s, U.S. postsecondary institutions began to attract more college applicants with less academic preparation. Due to poor or nonexistent public education for these applicants, the colleges took on the role of providing an equivalent high school education program that contained core subjects such as English and mathematics. An early model for this program was established at the University of Wisconsin in 1849. It was called the Department of Preparatory Studies. During the early to mid 1800s it was common for one-half or more students admitted to public colleges across the U.S. to graduate from these preparatory programs. The Wisconsin model was eventually adopted at most U.S. colleges by the late 1800s (Arendale, 2002).

There was considerable diversity regarding the administration of these programs. Sometimes it was located on the college campus and were overseen by the corresponding academic departments. Other times it was physically housed within the community, but still under administrative control by the college. A later model was for the program to be located in the public high school. With this setting, the program often had joint responsibility to the college and the school district (Arendale, 2002). There is some evidence that suggests that these academic preparatory programs served as the foundation for later development of junior colleges that eventually emerged from the public schools and gained their own autonomy. Not surprisingly, most public junior or community colleges still strongly promote academic preparation programs as core offerings of their curriculum.

\section{Remedial Education}

Remedial education was the term used by most in the field from the 1860s through the early 1960s. Remedial education often focused on specific skill deficits of students and educational approaches that addressed these identified needs. Clowes (1980) used the analogy of the traditional medical model when describing remedial education. Students were assessed for their academic weakness and then a prescriptive treatment was directed for the specific problem because these students were "academically backward or less able students" (Clowes, 1980, p 8). Academic treatments were repeated whenever the desired results were not obtained. Students were seen as possessing many academic deficits in need of prescriptive remediation. The focus of remedial education was primarily on cognitive deficits and not improvements in the affective domain.

In 1991 the College Reading and Learning Association Taskforce on Professional Language defined remedial as "instruction designed to remove a student's deficiencies in the basic entry or exit level skills at a prescribed level of proficiency in order to make him/her competitive with peers" (Rubin, 1991, p. 9). That document defined remedial students as students who are required to participate in specific academic improvement courses/programs as a condition of entry to college. College preparatory programs provided remedial courses as a primary vehicle for preparing students for entry to postsecondary education and successful enrollment in first-year level college courses. Involvement in remedial education was often seen as a prerequisite before enrollment in college graduation credit courses.

\section{Compensatory Education}

During the early 1960s, national civil rights legislation established the Office of Compensatory Education within the U.S. Office of Education (Chazan, 1973). The civil rights movement provided a slightly different perspective regarding the field of developmental education. Compensatory education described activities that remedied a previous state of discrimination.

Compensatory education in higher education would take the form of remediation activities such as preparatory and supplementary work...all with a program to provide an enriching experience beyond the academic environment to counterbalance a non-supportive home environment. (Clowes, 1980, p. 8)

Some believed that environmental conditions, often induced by poverty, were responsible for the poor academic achievement of some students. Frost and Rowland defined compensatory education as "those efforts designed to make up for the debilitating consequences of discrimination and poverty" (1971, p. vii). President Lyndon Johnson's War on Poverty was also a war on the conditions that required compensation for the poor environment that fostered it. In addition, such an education sought to provide an improved home environment, which was believed to be a significant factor for future academic achievement (Maxwell, 1997; Ntuk-Iden, 1978). 
Specific compensatory education programs such as TRIO, Equal Opportunity Programs, and others had their origins in the Civil Rights legislation of the 1960s. According to federal legislation, the only students eligible to be served through such programs had to meet one or more of the following conditions: (a) neither parent had completed college, (b) economically-disadvantaged background, and, (c) the student had an eligible disability. The TRIO college access programs became an official entitlement for a federally-defined subpopulation on the basis of race, ethnicity, and socioeconomic status (Kerstiens, 1997).

While remedial education was based on a medical model of identifying individual student deficits, compensatory education was based on the public health model (Clowes, 1980, p. 10). Rather than only focus on the individual, attention was expanded to the surrounding disadvantaged academic and economic environment with which the impacted individual interacts. Identification of student deficits, provision of remedial assistance, and addition of supplemental enrichment activities were essential for compensatory education. In addition to a curriculum that included remedial courses, compensatory education also sought to immerse students into a new learning culture that included enrichment activities.

\section{Learning Assistance}

The term learning assistance was introduced in the professional literature during the late 1960s (Christ, 1997). Synonyms commonly used by educators for this term are learning center or learning resource center. A review of the professional literature suggests that Frank Christ was the first person to use the phrase Learning Assistance Center in the professional literature. Maxwell states:

Learning assistance has a broader meaning in that it refers to programs

that offer academic skills help to all students -- from freshman to se-

niors and graduate students -- from those who need intensive work in

reading to those preparing for graduate and professional examinations.

Attendance in learning assistance programs tends to be voluntary

and students in the programs do not suffer from the stigma of being

viewed as dumb as those taking remedial courses usually do. (Piper,

1998, pp. 35-36)

Martin, Lorton, Blanc, and Evans (1977) echoed and expanded upon the position by Maxwell. The authors viewed the learning center in a much broader context with service not only to the traditional college student body, but also to the larger geographical local community within which the institution exists and interacts including the local school district and community education centers. The authors stated that:
A learning center is by definition a research center which can enhance experimental efforts in many fields. The learning center is also a development center, keeping current with new materials and techniques and adapting them to fit the needs of members of the institution. A learning center can also be an extension center which reaches into the community. (p. 3)

The College Reading and Learning Association defined learning assistance as a similar broad program of service to many within postsecondary education.

Supportive activities, supplementary to the regular curriculum, pro-

mote the understanding, learning, and remembering of new knowledge, remediation for prescribed entry and exit levels of academic proficiency, and the development of new skills. [They]...may provide study skills instruction, tutoring, reviews, Supplemental Instruction, study groups, special topic workshops, exam preparation, and various types of self-paced instruction, including computer-assisted instruc-

tion. (Rubin, 1991, p. 6)

Comprehensive learning centers were viewed as locations to serve students at all levels of academic preparation, even students who were classified as gifted. Carbone (1987) stated the goals of the learning center should include "development of the student's abilities to acquire and use information and enhancement of the teacher's ability to facilitate that development (p. 24). Martin et al. (1977) had a similar vision: "It is the major goal of the learning center to reinforce the faculty by providing assistance and support whenever requested" (p. 12). During the late 1960s and 1970s learning centers commonly provided alternative instructional delivery systems (e.g., audio cassette, video tape, independent study, computer-assisted instruction). This diverse suite of services provided a rich environment for students from differing levels of previous academic achievement to study academic content material until they attained the level of mastery that they desired. Such centers were often campus leaders for the effective introduction and use of technology-based instructional delivery (Arendale, 2004).

All students were invited and could benefit from the services of learning assistance, not just those who had specific, identified deficits or came from disadvantaged academic or economic backgrounds. In many ways, the learning assistance centers provided a model for the later learning/ teaching centers, which were established at some American colleges in the 1990s that were designed to provide assistance to both students and faculty members. Those centers focused not only on students improving their learning mastery of rigorous academic content material, but also as venues for faculty development. 


\section{Developmental Education}

Beginning in the 1970s, developmental education emerged as another term used by the field. This term was borrowed from the postsecondary education field of college student personnel. An underlying assumption is that all college students are developmental. "The notion of developmental sequence is the kingpin of developmental theory... A goal of education is to stimulate the individual to move to the next stage in the sequence" (Cross, 1976, p. 158).

While some within postsecondary education adopted this new term there were several notable exceptions. The first were the U.S. Department of Education and some other education agencies. They continue using the historic term "remedial education" to describe the same types of services that are commonly viewed as part of developmental education as well as more traditional remedial activities. Remedial education is the most commonly used technical term in federal legislation and regulations. Others who did not adopt developmental education were those who perceived that learning assistance was a more accurate descriptor because they provided services for all students on campus as described earlier in this article and disagreed with the perceived more narrow focus of developmental education.

Proponents of developmental education view it as a more comprehensive model regarding the student because it focuses on development of the person in both the academic and affective domains (Boylan, 1995 Casazza \& Silverman, 1996; Clowes, 1980). Rather than using the medical model focusing on the student's deficits or the public health model that also focused on the disadvantaged environment of a particular group of students, this value-added or talent development perspective assumes that each student has skills or knowledge that can be developed. Cross expressed the differences between remedial and developmental education in the following way:

If the purpose of the program is to overcome academic deficiencies,

I would term the program remedial, in the standard dictionary sense

in which remediation is concerned with correcting weaknesses. If,

however, the purpose of the program is to develop the diverse talents

of students, whether academic or not, I would term the program

developmental. Its mission is to give attention to the fullest possible

development of talent and to develop strengths as well as to correct

weaknesses. (Cross, 1976, p. 31)

The American Association of Community and Junior Colleges created a more expansive definition of developmental education. It recognized offering not only pre-collegiate-level courses (i.e., remedial courses), but other services which potentially serve all students wanting to increase their academic performance:

[Developmental education programs] teach academically underprepared students the skills they need to be more successful learners. The term includes, but is not limited to, remedial courses... Effective developmental education programs provide educational experiences appropriate to each student's level of ability, ensure standards of academic excellence, and build the academic and personal skills necessary to succeed in subsequent courses or on the job. Developmental programs are comprehensive in that they access and address the variables necessary at each level of the learning continuum. They employ basic skill courses, learning assistance centers, Supplemental Instruction, paired courses and counseling. (AACJC, 1989, p. 115)

A comprehensive collection of definitions was compiled by a taskforce commissioned by the College Reading and Learning Association that related to developmental education (Rubin, 1991). These definitions have been accepted by the major developmental education and learning assistance associations. The definition for "developmental education" in this document provides a broader perspective regarding the service area for the profession than the definition by the AACJC. Developmental education was defined as:

1: a sub-discipline of the field of education concerned with improving the performance of students. 2: a field of research, teaching, and practice designed to improve academic performance. 3: a process utilizing principles of developmental theory to facilitate learning. (Rubin, 1991, p. 4)

This definition has been revised and expanded by the National Association for Developmental Education. The scope of service by developmental education was extended to the entire student body throughout the institution because all students were viewed as developmental:

Developmental education is a field of practice and research with a theoretical foundation in developmental psychology and learning theory. It promotes the cognitive and affective growth of all learners, at all levels of the learning continuum. It is sensitive and responsive to the individual differences and special needs among learners. (NADE, 1996, p. 1)

In the later portion of 1990s, the perception of developmental education changed for some, and not for the better. Critics of developmental education equated it with compensatory and remedial education with the associated perceived negative baggage that accompanied both of those terms. In 1998 Maxwell noted:

.developmental education has become a euphemism for remedial with 
all the negative connotations that word implies... Today, students taking developmental courses are stigmatized...in primary and secondary schools the term developmental education applies to programs for the mentally retarded. (Piper, 1998, p. 35)

Much in the same way that remedial education engendered negative reactions from some policy makers, developmental education has attracted similar negative status among a growing number of people in recent years. To confront these perceptions, some argue that developmental education must grow in its theory to reflect current scholarship and effective practices that will result in wider acceptance and influence (Lundell \& Collins, 1999).

\section{Access Programs}

Thus far this review of terminology has focused on its use within United States postsecondary education. A review of similar programs in the United Kingdom (U.K.) provides different terminology. Unlike the U.S., higher education in most countries is coordinated, funded, and evaluated by the national government. Two organizations that provide leadership with widening participation in higher education by historically-underrepresented student groups in the U.K. are the European Access Network (2004) and the Institute for Access Studies (2003). Most U.K. postsecondary institutions offer student services similar to U.S. colleges that support student success such as advising, counseling, disability services, orientation, mentoring, and tutoring (Thomas, Quinn, Slack, \& Casey, 2002, 2003)

One noticeable difference between the U.S. and the U.K. concerns academic-term length remedial or developmental courses. Such courses may be centralized or distributed with academic units throughout the local U.S. postsecondary institution. In some cases such courses at public institutions have been banned by local or state education officials. The burden within U.S. colleges is very unequal. Public institutions, especially two-year colleges, bear the responsibility for such course of ferings. There is no similar expectation for private institutions. There are significant differences among policies among the states regarding developmental education. A few states have created state-funded access and equal opportunity programs to extend similar programs provided by the federal government (e.g., CA, NJ, NY, PA). The U.K. has taken a different approach by organizing these courses into an institutional unit called an Access Program. These programs may be located within a postsecondary institution or an adult education center operating independently in the community. Successful completion of the one year program results in the receipt of a certificate of completion and eligibility to enter a degree program at a college or university. There are some similarities between access programs and academic preparatory programs described earlier in this article. This is not surprising because many early U.S. colleges were designed to replicate higher education models in the U.K. and Germany. An important difference between the U.S. and the U.K. is that U.S. colleges are more likely to admit students who have less academic preparation than are U.K. institutions, which have higher admission standards. U.S. institutions are more often willing to admit students to determine whether they can benefit from the college experience than U.K. institutions that demand a higher level of likelihood of academic success before admission (A. Policicchio, personal communication, February 18, 2005).

Access programs were first initiated by the U.K. national government in 1978. In addition to this proactive stance by the national government, there are several distinctive features of access programs: (a) officially recognized as a route into further higher education; (b) meet minimum standards by the national government before they are permitted to begin; (c) targeted for under-represented students in U.K. higher education such as disabled learners, the unemployed, female returners, minority ethnic groups, and those from lower socio-economic backgrounds; and (d) rigorously evaluated by the Quality Assurance Agency, a national government agency similar to the U.S. Government Accounting Office (UCAS, 2003a, 2003b, 2003c).

The U.K. model offers several potential advantages in comparison with the highly decentralized and diversified system of U.S. higher education. U.K. access programs are highly regulated and evaluated by standards established by the national government's education department rather than voluntary compliance with standards established by professional associations (i.e., College Reading and Learning Association, Council for the Advancement of Standards, National Association for Developmental Education, National Tutoring Association). Institutional funding is contingent positive student outcomes, including similar demographic profiles of both the college admits and the graduates. Because access programs are authorized by the national government, there is not the friction concerning their existence that sometimes faces counterpart programs in the U.S. Due to their constant evaluation by a government agency, access programs are perceived as a rigorous entry path to higher education.

Future Terminology and Vision

Academic preparatory programs, remedial education, compensatory 
education, learning assistance, developmental education, and access programs are terms that at one time or another have been used to describe the field and practice. Each has specific meanings and often evokes quite different perceptions. History teaches us that new vocabulary will emerge to describe this work, especially if the form and range of services significantly change.

The diversity of names is reflected by the American and European professional associations and organizations that directly or indirectly represent the interests of the field: Association of Tutoring Professionals, College Reading Association, College Reading and Learning Association, Commission for Academic Support in Higher Education (unit within the American College Personnel Association), Council for Opportunity in Education, European Access Network, Institute for Access Studies, Learning Support Centers in Higher Education, National Association for Developmental Education, National Center for Developmental Education, National College Learning Center Association, National Orientation Directors Association, National Tutoring Association, among others. Payne and Lyman (1996) state that there is an identity problem, if no an identity crisis within the profession that is of such magnitude that renaming the profession again is an option to deal with the problem (p. 13). Rather than only focusing on language, Gardner (2000) expands upon this pressing need for transformation by exhorting the profession to reengineer itself through development of new language, partnerships, objectives, and programs.

Concern about careful selection of language used to describe the profession has been stated previously by others (Clowes, 1980; Gardner, 2000; Higbee, 1993, 1996; Maxwell, 1997; McGrath E Spear, 1994). Scholars at several institutions have conducted research studies with students that revealed the negative stigma that many felt due to their participation in developmental education programs (Pedelty, 2001; Valeri-Gold, \& others, 1997). While the issue of redefining the field has been a reccurring theme in history, the urgency to carefully reevaluate the language has never been more dramatic with increased restrictions and some curtailment of programs, especially at the public four-year level (Barefoot, 2003; Jehangir, 2002; Martinez, Snider, \& Day, 2003).

If professionals are not clear and proactive in defining the field, the field will be subject to definition and labeling by ill-informed politicians who often use antiquated and inaccurate words to define practice (Rubin, 1987). Collaborative work among several of the professional associations has produced several glossaries of key terms related to developmental education and learning assistance (Rubin, 1991, 1992; Clark-Thayer, 1995). After a decade, I believe it is time to again engage in assessment by incorporating new language that more accurately describes the field. As our practice advances and changes, so must the language to describe it.

In recent years the education professional journals have published more articles concerning student learning outcomes and identification of new approaches to teaching (Lazerson, Wagener, \& Shumanis, 1999). An influential article published in 1995 recommended a shift to the newer learning paradigm (Barr $\mathbb{E}$ Tagg, 1995). This was one of the most discussed and reprinted articles of the 1990s and helped to foster faculty development programs as well as increase focus on assessing studen learning outcomes. The article indirectly impacted developmental education because it gave opportunity for some campus faculty members and policymakers to reinterpret its work as more essential for supporting increased learning outcomes than earlier believed. Astin (1998) advocated that higher education reorient itself from its preoccupation with identifying talented new freshman for admission (identifying smartness) to focusing on a value-added, talent-development (developing smartness) evaluation model. He argued that it was in the best interests of society that academic enrichment programs are provided for all college students to increase the number of highly trained graduates ready to meet the requirements for citizenship and leadership in the country.

A practical expression of this talent-development approach was advanced by Pedelty and Jacobs (2001). The majority of students enrolled in their classes would have been placed into traditional remedial or developmental education courses at other institutions. Instead, these teachers employed a cultural study framework that combined anthropological and sociological groundings that expanded their students' existing expertise, rather than focusing effort to replace or remedy their so-called deficits. This approach was used successfully by these faculty members in thei social science courses without the need for prerequisite or concurrent enrollment in developmental education course work.

Although many writers advocate for more support programs to run in parallel with instructional programs, some in higher education promote more integrated and seamless approaches to academic learning and student development for all students. The American College Personnel Association and the National Association of Student Personnel Administrators created a statement concerning a new definition for transformative learning in education. The joint statement was titled Learning Reconsidered.

Learning Reconsidered is an argument for the integrated use of all of higher education's resources in the education and preparation of the whole student. It is also an introduction to new ways of understanding 
and supporting learning and development as intertwined, inseparable elements of the student experience. It advocates for transformative education's holistic process of learning that places the student at the center of the learning experience. (Keeling, 2004, p. 1).

Perhaps these authors have provided guidance for developmental education regarding future language and mission. There has been a movement over the past several decades to mainstream more of our work into the heart of the institution and within the core curriculum. Examples of this movement include: (a) offering noncredit learning services for all students, (b) involvement with learning communities, (c) providing class-based tutoring, (d) supporting distance and online learners, (e) embedding best practices of developmental education within core curriculum courses, and (f) facilitating faculty development services. Best practices within the profession promote and support the holistic development of students. While adopting this view of student development may be a recent conversion experience by some faculty members and policymakers, many of us have been faithfully engaging in this work for a long time. We need to articulate language to help others better understand and support our efforts. New language may help all of us to recognize our common goals. That conversation can lead to more support for our students and better positioning of our programs to meet institutional priorities.

I am reminded of the old saying, form follows function. .As our work changes, so should the language used to describe it. Let us select language not on the basis of past history, current perceptions or political advantage, but on what we actually do and the impact that results for our students. Words are important.

\section{References}

Abraham, A. A., \& Creech, J. D. (2000). Reducing remedial education: What progress are states making? Educational Benchmark 2000 Series. Atlanta, GA: Southern Regional Education Board. Retrieved August 19, 2004, from http://www.sreb.org

American Association of Community and Junior Colleges. (1989). Policy statements of the American Association of Community and Junior Colleges. In American Association of Community and Junior Colleges Membership Directory. Washington, D.C.: Author.

Arendale, D. (2002). Then and now: The early history of developmental education: past events and future trends. Research \& Teaching in Developmental Education, 18(2), 3-26. Arendale, D. (2004). Mainstreamed academic assistance and enrichment for all students: The historical origins of Learning Assistance Centers. Research for Education Reform, 9(4), 3-21.

Astin.A. W. (1998). Remedial education and civic responsibility. National Crosstalk, 6(2), 12-13. Retrieved July 4, 2004, from http://www.highereducation.org/crosstalk/pdf/ct- summer98.pdf

Barefoot, B. O. (2003). Findings from the Second National Survey of First-Year Academic Practices. Brevard, NC: Policy Center for the First Year of College. Retrieved July 4 , 2004, from http://www.brevard.edu/fyc/survey2002/findings.htm

Barr, R. B., \& Tagg, J. (1995). From teaching to learning: A new paradigm for undergraduate education. Change Magazine, 27(6), 13-25. Retrieved July 4, 2004, from http://critical. tamucc.edu?!blalock/readings/tch2learn.htm

Boylan, H. R. (1995). Making the case for Developmental Education. Research in Developmental Education, 12(2), 1-4.

Brier, E. (1984). Bridging the academic preparation gap: An historical view. Journal of Developmental Education, 8(1), 2-5.

Carbone, G. J. (1987). Academic support services for developmental and high-risk students in community colleges. In K. M. Ahrendt (Ed.), New directions for community colleges (pp. 23-32). San Francisco: Jossey-Bass.

Casazza, M. E., \& Silverman, S. L. (1996). Learning assistance and developmental education: A guide for effective practice. San Francisco: Jossey-Bass.

Chazan, M. (1973). Compensatory education. London, England: Butterworth.

Christ, F. L. (1997). The Learning Assistance Center as I lived it. In S. Mioduski, \& G. Enright (Eds.), Proceedings of the 15th and 16th annual institutes for learning assistance professionals: 1994 and 1995 (pp. 1-14). Tucson, AZ: University Learning Center, University of Arizona. Retrieved August 19, 2004, from http://www.pvc.maricopa.edu/winterinstitute/proceedings/945_proc/945proc_christ.html

Clark-Thayer, S. (Ed.). (1995). A glossary of developmental education terms. In S. ClarkThayer (Ed.). NADE self-evaluation guides: Models for assessing learning assistance/developmental education programs (pp. 165-174). Clearwater, FL: H\&H Publishing.

Clowes, D. A. (1980). More than a definitional problem: Remedial, compensatory, and developmental education. Journal of Developmental and Remedial Education, 4(1), 8-10. Cross, K. P. (1976). Accent on learning. San Francisco: Jossey-Bass.

European Access Network. (2004). Homepage. Retrieved August 12, 2004, from http:// www.wmin.ac.uk/ean/

Frost, J., \& Rowland, G. (1971). Compensatory education: The acid test of American education. Dubuque, IA: William C. Brown.

Gardner, J. (2000). The changing roles of developmental educators. Journal of College Reading and Learning, 31(1), 5-18.

Higbee, J. L. (1993). Developmental versus remedial: More than semantics. Research \& Teaching in Developmental Education. 9, 99-105.

Higbee, J. L. (1996). Defining developmental education: A commentary. In J. L. Higbee \& P. L. Dwinell (Eds.). Defining developmental education: Theory, research, and pedagogy (pp. 63-66). Carol Stream, IL: National Association for Developmental Education.

Institute for Access Studies. (2004). Homepage. Retrieved August 12, 2004, from http:// www.staffs.ac.uk/institutes/access

Jehangir, R. R. (2002). Higher education for whom? The battle to include developmental 
education at the four-year university. In J. L. Higbee, D. B. Lundell, \& I. M. Duranzyk (Eds.), Developmental education: Policy and practice (pp. 17-34). Auburn, GA: National Association for Developmental Education.

Keeling, R. P. (Ed.). (2004). Learning reconsidered: A campus-wide focus on the student experience. Washington, D.C.: American College Personnel Association and National Association of Student Affairs Administrators. Retrieved January 29, 2005, from http://www.myacpa.org/pub/documents/LearningReconsidered.pdf

Kerstiens, G. (1997). Taxonomy of learning support services. In S. Mioduski, E G. Enright (Eds.), Proceedings of the 15th and 16th annual institutes for learning assistance professionals: 1994 and 1995 (pp. 48-51). Tucson, AZ: University Learning Center, University of Arizona. Retrieved August 19, 2004, from http://www.pvc.maricopa.edu/ lsche/proceedings/945_proc/945proc_kerstiens.htm

Lazerson, M., Wagener, U., \& Shumanis, N. (1999). What makes a revolution: Teaching and learning in higher education, 1980-2000. Stanford, CA: National Center for Postsecondary Improvement, Stanford University. Retrieved July 4, 2004, from http://www.stanford.edu/group/ncpi/documents/pdfs/5-11_revolution.pdf

Lundell, D. B., \& Collins, T. (1999). Toward a theory of developmental education: The centrality of "discourse". In J. L. Higbee, \& P. L. Dwinell (Eds.), The expanding role of developmental education (pp. 3-20). Morrow, GA: National Association for Developmental Education.

Martin, D. C., Lorton, M., Blanc, R., \& Evans, C. (1977). The learning center: A comprehensive model for colleges and universities. Kansas City, MO: University of Missouri (ERIC Document Reproduction Service, No. ED 162294).

Martinez, S., Snider, L. A., \& Day, E. (2003). Remediation in higher education: A review of the literature. Topeka, KS: Kansas State Board of Education. Retrieved July 4, 2004, from http://www.ksde.org/pre/postsecondary_remediation.doc

Maxwell, M. (1997). Improving student learning skills: A new edition. Clearwater, FL: H\&H Publishing Company.

McGrath, D., \& Spear, M. B. (1994). The remediation of the community college. In J. L. Ratcliff, S. Schwarz, \& L. H. Ebbers (Eds.). Community colleges (pp. 217-228). Needham Heights, MA: Simon \& Schuster

National Association for Developmental Education. (1996). Developmental education goals and definition. Retrieved August 19, 2004, from http://www.nade.net

Ntuk-Iden, M. (1978). Compensatory education. Westmead, England: Teakfield Limited.

Payne, E. M., \& Lyman, B. G. (1996). Issues affecting the definition of developmental education. In J. L. Higbee, \& P. L. Dwinell (Eds.), Defining developmental education: Theory, research, and pedagogy (pp. 11-20). Carol Stream, IL: National Association for Developmental Education

Pedelty, M. H. (2001). Stigma. In J. L. Higbee, D. B. Lundell, \& I. M. Duranzyk (Eds.). 2001: A developmental odyssey. Warrensburg, MO: National Association for Developmental Education.

Pedelty, M. H., \& Jacobs, W. R. (2001). The place of “culture” in developmental education's social sciences. In D. B. Lundell, \& J. L. Higbee (Eds.). Theoretical perspectives for developmental education (pp. 75-90). Minneapolis, MN: Center for Research in Developmental Education and Urban Literacy, General College, University of Minnesota. Retrieved July 4, 2004, from http://www.gen.umn.edu/research/crdeul/monographs.htm

Piper, J. (1998). An interview with Martha Maxwell. The Learning Assistance Review, 3 (1), 32-39.

Rice, P. (1980). The quality of language and thought in developmental education. Journal of Developmental and Remedial Education, 4 (1), 9-10

Rubin, M. (1987). What's in a name: The need for resolution of terminology confusion in developmental education. Journal of College Reading and Learning, 20 (1), 8-15.

Rubin, M. (1991). A glossary of developmental education terms compiled by the CRLA Task Force on Professional Language for College Reading and Learning. Journal of College Reading and Learning, 23 (2), 1-14.

Rubin, M. (Ed.). (1992). A glossary of developmental education terms. Salem, OR: College Reading and Learning Association.

Thomas, L., Quinn, J., Slack, K., \& Casey, L. (2002). Student services: Effective approaches to retaining students in higher education. Stoke-on-Trent, United Kingdom: Institute for Access Studies, Staffordshire University. Retrieved January 31, 2005, from http://www.staffs.ac.uk/institutes/access/docs/SSReport.pdf

Thomas, L., Quinn, J., Slack, K., \& Casey, L. (2003). Effective approaches to retaining students in higher education: Directory of practice. Stoke-on-Trent, United Kingdom: Institute for Access Studies, Staffordshire University. Retrieved January 31, 2005, from http://www. staffs.ac.uk/institutes/access/docs/Directory1.pdf

Universities \& Colleges Admission Service. (2003a). Homepage. Retrieved January 31, 2005, from http://www.ucas.com/access/

Universities \& Colleges Admission Service. (2003b). Questions asked by higher education admissions staff. Retrieved January 31, 2005, from http://www.ucas.com/ucc/access/ ewni/staff.html

Universities \& Colleges Admission Service. (2003c). Questions asked by potential applicants, their advisers and admissions staff. Retrieved January 31, 2005, from http://www.ucas.ac.uk/ucc/access/ewni/questions.html

Valeri-Gold, M., Callahan, C. A., Deming, M. R., Mangram, M. T., \& Errico, M. (1997). Reflection: Experience commentaries by urban developmental studies students. In J. L. Higbee, \& P. L. Dwinell (Eds.). Developmental education: Enhancing student retention (pp. 3-18). Carol Stream, IL: National Association for Developmental Education.

David Arendale is an Assistant Professor in Social Sciences with the General College of the University of Minnesota-Twin Cities and advisor for the Center for Research on Developmental Education and Urban Literacy. Arendale investigates the history of postsecondary college access, developmental education, and academic interventions that support improved student achievement and persistence. Previously, Arendale 
served at the University of Missouri-Kansas City in several capacities including National Project Director of Supplemental Instruction. At both the community college and public four-year college level Arendale has directed comprehensive learning centers. Correspondence regarding this article should be addressed to him at 262 Appleby Hall, 128 Pleasant Street SE, Minneapolis, MN 55455, Telephone: 612-6252928.E-mail: david@arendale.org 